Florida International University FIU Digital Commons

$8-1989$

\title{
A study to determine the effectiveness of employee hiring programs in the catering business in the south Florida area
}

Jong-Hoon Chung

Florida International University

DOI: $10.25148 /$ etd.FI14060827

Follow this and additional works at: https://digitalcommons.fiu.edu/etd

Part of the Hospitality Administration and Management Commons

\section{Recommended Citation}

Chung, Jong-Hoon, "A study to determine the effectiveness of employee hiring programs in the catering business in the south Florida area" (1989). FIU Electronic Theses and Dissertations. 2357.

https://digitalcommons.fiu.edu/etd/2357 


\section{A STUDY TO DETERMINE THE EFFECTIVENESS \\ OF EMPLOYEE HIRING PROGRAMS IN THE CATERING BUSINESS IN THE \\ SOUTH FLORIDA AREA}

\section{An Industry project \\ Presented To \\ The Faculty of}

The School of Hospitality Management

Florida International University

In partial Fulfillment

Of The Requirements For The Degree of

\section{MASTER OF SCIENCE}

By

JONG-HOON CHUNG

August 1989

Commitee in Charge:

Professor Elio Bellucci

Professor Roger Probst 
To Professors Bellucci and Probst

This project, having been approved in respect to form and mechanical execution, is referred to you for judgment upon its substantial merit.

Anthony G. Marshal1, J.D., Dean School of Hospitality Management

The project of Jong-Hoon Chung is approved.

Elio Bellucci, J.D. Associate Professor

Roger Probst, Lecturer 


\title{
ABSTRACT
}

\begin{abstract}
A STUDY TO DETERMINE THE EFFECTIVENESS OF EMPLOYEE HIRING PROGRAMS IN THE CATERING BUSINESS IN THE SOUTH FLORIDA AREA
\end{abstract}

by

JONG-HOON CHUNG

The purpose of this study was to determine the effectiveness of employee hiring programs in the catering business in the South Florida area. The descriptive survey method was used for the gathering of the primary data source. The study was conducted by supporting the hypothesis. The hypothesis stated that employee hiring programs in the catering business in the South Florida area are generally ineffective. 
ACKNOWLEDGEMENTS

The writer would like to take this opportunity to express his deep appreciation to the many faculty members who have helped him in the preparation of this project. Special thanks to Professor Norman Ringstrom, Elio Bellucci and Roger Probst for their guidance and assistance that they have given the writer as advisors for this project and for their excellent, professional counseling through the entire program.

A special appreciation to those managers of selected catering companies who took time out of their busy schedules to provide the writer with their knowledge and expertise.

Finally, the writer would like to thank his parents and his wife, Mi-Jin, for being supportive in every way, for providing and encouraging him the opportunity to achieve a valuable education at Florida International University. 


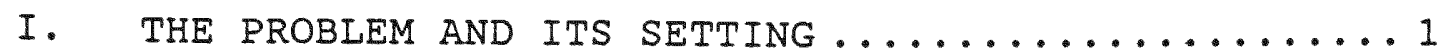

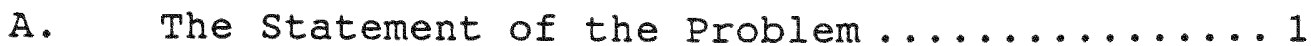

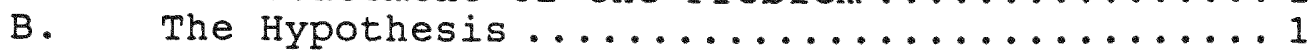

C. The Delimitations ...................

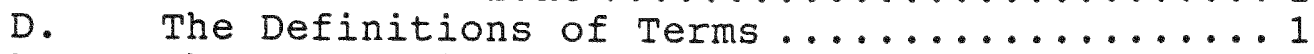

E. The Assumptions ....................

F. The Importance of the study ............

II. THE REVIEW OF THE RELATED LITERATURE ......... 5

A. Background and Trends in Catering Business .. 5

B. The Outline of the Catering Industry ......7

C. The Successful Development of the

Catering Business ................ 15

D. The Projection to the Year 2000 in the

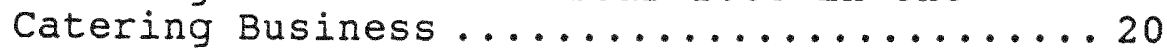

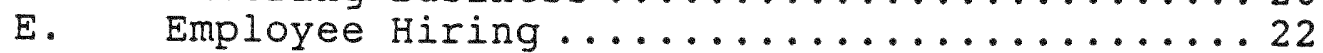

F. Employee Hiring Programs and Steps ........23

II. THE DATA AND THE TREATMENT OF THE DATA ........ 58

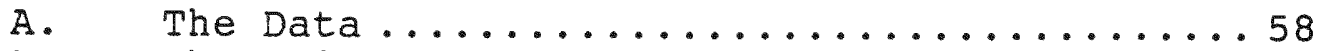

B. The Criteria Governing the Admissibility

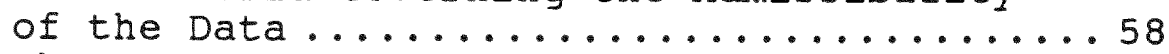

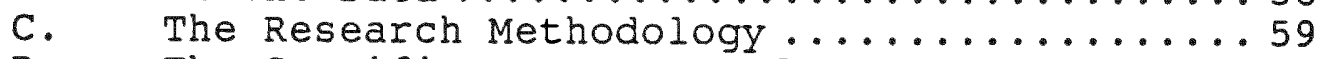

D. The Specific Treatment of Data for

the Problem ....................61

IV. GENERAL PROCEDURE ................... 64

A. The Population of the study ..........64

B. Collection Procedure...............6 64

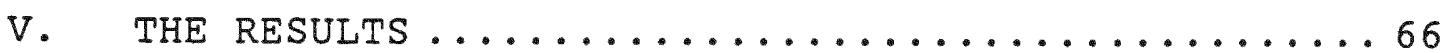

A. Questionnaire Findings ............66

B. Assessment of Findings ............ 72

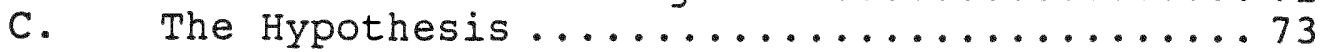

D. Concluding Remarks ...................... 74

VI. CONCLUSIONS AND RECOMMENDATIONS ............ 75

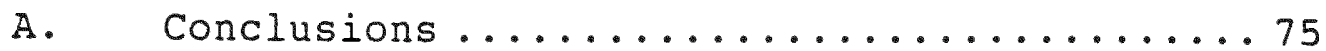

B. Recommendations .................. 76

SELECTED BIBLIOGRAPHY ................... 80 APPENDICES ........................... 83 QUALIFICATIONS OF THE RESEARCHER ............... 87 
I. THE PROBLEM AND ITS SETTING

A. The statement of the Problem

The purpose of this study is to determine the effectiveness of employee hiring programs in the catering business in the South Florida area.

B. The Hypothesis

The Hypothesis is that employee hiring programs in the catering business in the south Florida area are generally ineffective.

c. The Delimitations

1. The study will be limited to the catering business in the South Florida area.

2. The study will be limited to hiring programs for all employees.

D. The Definitions of Terms

Hiring: Hiring can be defined as the contract or relationship between the parties to a transaction in which one hires the services or property of the other. ${ }^{1}$

Effectiveness. Effectiveness is the quality or state of being effective, marked by the quality of being influential or exerting positive influence. ${ }^{2}$

${ }^{1}$ Philip Babcock Gove, Webster's New International Dictionary, ed. 3, The Merriam-Webster Co., Inc., 1986.

${ }^{2}$ Ibid. 
Catering Business. This business is a segment of the hospitality industry to provide a supply of usually prepared food, service and entertainment. ${ }^{3}$

E. The Assumptions

The first assumption. The first assumption is that hiring programs are very effective management tools. The second assumption. The second assumption is that catering business needs effective hiring programs in order to achieve their organizational goals.

F. The Importance of the study

Most companies have long recognized that the success of their organizations depends greatly on the quality of their personnel.

Employee hiring programs has been a continuing problem for personnel departments throughout the industry.

Research and experience has shown that programs which are related to hire employees are not effective, and people who are responsible for hiring programs in the catering business do not always have the skills and knowledge that are necessary to make effective hiring programs.

of all the variables that contribute to the success and viability of an organization, none is more important than the quality of the people involved. Therefore, it is not at all surprising that companies are so eager to attract, hire,

${ }^{3}$ Ibid. 
and retain a productive satisfied, and well motivated staff. Having a knowledge of the people being trained and their culture and related problems (social, economic and political), the hiring staffs will better understand their applicants and again hiring employee programs can be more effective.

Usually when hiring staff begin hiring employees to operate the store, they encounter great difficulties. They need good advertisement programs to find more qualified employees. If they hire unqualified people, they will be confronted by high employee turnover.

The widespread belief is that employee turnover has a negative result on effectiveness and productivity. As the author mentioned before, effectiveness is the degree to which an organization achieves its goals.

Because of the labor intensive nature of the hospitality industry, proper hiring programs play an important role. For the employer a good hiring program has value because it reduces labor turnover, reduces absenteeism, reduces accidents, increases production and it improves morale.

For the employee, proper hiring has value because it enhances self-respect and it gives the feeling of strong affection to his or her company.

Whether a catering business has formal and adequate employee hiring programs or improper hiring programs, the person who is going to put it to work is a valuable asset of 
the company. How well qualified that person is will determine whether the highest quality products are produced at the lowest possible expenditure of time and money.

Effective staffing and success in recruiting and selecting truly capable people will be an asset to the company, and requires a certain amount of time, effort and careful attention in the employee hiring process.

Undertaking this study, the author will also try to exploit the potential of proper hiring employee programs to meet the problems and challenges of making hiring responsible, effective, and cost effective.

The development of good hiring programs in the catering business will reduce many problems due to ineffectiveness. 
II. THE REVIEW OF THE RELATED LITERATURE

A. Background and Trends in Catering Business

As one reviews the background of the food service industry in the United States, and as one attempts to analyze current trends and project future developments, it is well to keep in perspective the historical development of this industry over the years. Let us, therefore, turn the clock of history back, say about 500 years, to the year 1475, some seventeen years before that famous day in October of 1492 when Columbus had his first glimpse of America, and eight years before the birth of Martin Luther. In Venice, Platina published the first cookbook, called on Honest Indulgence and Good Health. Platina wrote:

A cook must be a man schooled by art and long experience, patient in his work, and one who wishes to be greatly pleased for it. He should know everything about the nature of meats, fish and herbs, so that he can distinguish what should be roasted, boiled or fried. He should have the taste to be able to tell what is too salty or too bland. ${ }^{4}$

${ }^{4}$ Platina (1475). De Aguila, Venice (From the Mallinckrodt collection of food classics). 
In the first century $A D, P l i n i u s$ secundus--better known as "Pliny the Elder" said about food service in his book Natural History.

But it was not necessary to read "Pliny the Elder" to ascertain the state of the art of food service during that the first century $A D$.

We can conclude this brief glimpse into the recorded history of mankind in so far as food service industry. First, as one would say in French, "le plus que cela change, le plus que cela reste le même." Secondly, it is clear that certain fundamental aspects and concerns relating to food service have remained unchanged since the earliest days of history:

1. The need for food service itself, especially in relation to catering to the needs of travelers

2. The interest in good food and its attractive presentation

3. The interest in international cuisine

4. The awareness of the relationship of food to health and--even as we just saw in the Bible--

5. The need for credit

Although we need not look for fundamental changes in food service as we examine the recent history of the industry in the united states, it is nevertheless clear that the last three decades have brought forth economic and structural changes--many resulting from changes in lifestyle-- 
which have significantly affected the industry and its methods of operation. 5

B. The outline of the Catering Industry

In the years since the end of the second world war the catering industry has made great strides in its economic performance and is seen to have done so in the eyes of the general public and government.

The first statutory recognition of catering services was the Catering Wage Act of 1943 which resulted in the setting-up of the Catering Wages Commission and of Wages Boards for the industry. The Commission published several reports on a wide range of aspects of the industry including the 1946 report "Training for the Catering Industry," which summarized the stage of catering education and made important recommendations.

The emergence of an identity for the industry was reinforced by its inclusion in the Standard Industrial Classification 1948 and its subsequent successors. Thus the wide range of organizations operated with a view to profit are included: hotels, motels, holiday camps, guest houses, boarding houses, hostels, restaurants, cafes, snack bars, milk bars, coffee bars, refreshment rooms, tea shops, function rooms, fish and chip shops, ice cream parlours, public

${ }^{5}$ George Glew, Advances in Catering Technology, (London, England: Applied Science Publishers, Ltd.), 1980, p. 18. 
houses, residential and licensed clubs, industrial canteens and school canteens.

But the classification does not include catering activities provided as a service to some other main function of the organization. Non-catering companies operating their own staff restaurants, hospital meals and school meals ... are examples of activities not included. ${ }^{6}$ other influences have contributed to the growing importance of the hotel and catering industry: the growth in consumer expenditure, changes in the economic and social structure, the rapid development of international tourism, recognition of the value of service industries as employers and the work of professionals, trade and government bodies.

Catering is too broad a category to refer to as a single market. The distinction depends on what catering segment you are addressing:

1. Social catering.

Home parties, weddings, debutante parties, confirmations, baptisms, and so on.

2. Product catering.

Being known for baked goods, steaks, ribs, barbecues, wedding cakes, picnic lunches, and so forth.

3. Corporate catering.

${ }^{6}$ Roy Hayter, A Career in Catering, (Pergamon Press), 1980, p. 7. 
Executive lunches and dinners, office parties, promotion celebrations, receptions, contribution and charity events, etc.

Within the social segment, you build your reputation by these methods:

a. Use complimentary letters.

b. Have high quality photographs taken of your products and presentations.

c. Invite key clients and decision-makers to see exactly what you do, and let them participate in tasting.

d. Make every sales proposal and party execution perfect.

If you are involved with catering certain products, you must try utilizing the following direct approaches:
a. Brochures highlighting the item or items
b. Receptive announcements or advertisements
c. Direct mail and promotions
d. Free samples to large clients

And the corporate division must be subdivided into three distinct types of business:

a. Shallow

In this market, you should spend time reinforcing consistency, quality, cost effectiveness, and punctuality. You utilize direct 
mail, personal visits, and good, simple brochures.

b. Mid-level

Marketing here has the features of the shallow market but you must carry some measure of reputation, innovativeness, and attention to detail.

c. Deep.

You must have a well-established reputation because very few shoppers will pick your company from the Yellow Pages. You can contact your party planners and show them what you can do, have done, will do. And you have to develop relationships with people in charge of places where companies want to hold parties. So it is important to spend your money one-on-one with the people who count.

Marketing for catering is almost impossible to outline briefly. But without these fundamentals, entering the catering game successfully can be as easy as trying to put out a raging fire with a squirt gun.

Contract catering

Contract catering recognizes the role of good hotel or restaurant design and improved facilities have played in improving workers' productivity. 
According to ICC Business Ratios' survey, the catering industry, which includes operators of airport and motorway service areas among the contractors surveyed, during the financial year 1983-84 sales grew by an average of 36 percent and profits rose by an average of 25 percent.

Return on capital in that year stood at 17.2 percent while profit margins averaged 4.1 percent. The results for the last financial year also looking encouraging, the report says.

The survey analyzes 35 catering contractors and 65 catering equipment manufacturers.

Contract caterers have responded to the challenge by being flexible--and flexibility of mind is the attribute the rest of the food service industry can emulate. This is particularly productive when the contract caterer has some of the skills of public catering. Flexibility means recognizing that different people have different needs. Segmenting the market is something which every single establishment can do. 7

Off-Premise Catering

An increasingly wide range of operations are catering off-premise today--not only restaurants, but hotels, supermarkets, and universities. Michael Roman, President of the Chicago-based National Institute for off-Premise Catering, Industrial Caterer, (December 1984/January 1985), p. 4. 
reports an ongoing blossoming of off-premise catering. "We are not witnessing the spread of the customization of hospitality," says Roman, "sought by those who really prefer to do it themselves." 8

More and more restaurants are offering catering services, since more and more profit is appearing in the offpremise scene.

Catering is a personal care business so this type of business must advertise its identity to the customers. Advertising is the message transmitted through everything to you. Paid advertising in magazines, newspapers, on radio and TV represents a part of what you need to consider. So the advertising process must be followed by defining yourself. Then you must apply what you want to promote about yourself to the types of advertising.

1. Image Advertising

Image advertising creates an impact, and hopefully leaves an indelible impression on the recipient. It is used to reinforce the image you want to project. Here is how an image is created:

1) Clarity as to who you are and what you are good at.

2) Your most recent function.

3) A simple, memorable name.

8"Off-Premise Catering," Restaurant Business, (October $10,1987)$, p. 201. 
4) A contemporary logo

5) Consistently attractive, appetizing colors and graphics

6) Your product quality

Each of these factors play a part in the building of your reputation and your image. The purpose is to create word-of-mouth advertising. Good imaging advertisement work best in magazines and on radio and $T V$, due to the impact of sight and sound. Image advertisements are generally:

1) designed to reinforce an image, not sell a specific product or service.

2) simple and uncluttered.

3) difficult to track sales.

4) more effective in the higher income market segment.

Both social and corporate catering rely on reputation enhancement for expansion and subtle image building through placement of good advertisements, positive editorial pieces, goodwill gestures in the community and quality promotions."

\section{Direct Advertising}

Direct advertising has been described as the shortest link between buyer and seller. It is most effective when specifying a certain product or service. Typical direct advertising includes the use of direct mail (or other dis-

9 Jay Tradewel1, "Off-Premise Catering: How to Advertise," Restaurant Hospitality (May 1987), p. 52. 
tribution methods for brochures), newspapers, magazines, Yellow Pages, radio and TV.

1) Direct mail should target a specific market and is traceable with statistical accuracy. In the form of research, it can provide valuable demographic feedback so as to guide positioning efforts.

2) Newspapers are appealing because of their relatively low cost per insertion, but the advertisements repetition viewing--the most effective principle of any advertising--is reduced by the "daily-ness" of the medium.

3). Magazines, though more expensive, are seen more times by a more targeted audience.

4). Yellow Pages are a wonderful form of advertising for new companies or ones who are known for products they want to sell.

5) Radio and Television reach the largest number of people, but care must be taken to understand the market you will reach. Television is very effective yet so expensive that it is all but prohibitive for small businesses. Some caterers, though, have gotten good results for far less money by making use of cable TV networks. 
C. The successful Development of Catering Business

Catering can often make the difference between success and failure for leisure industry operators. The catering business brings opportunities for many, and helps formulate the wave of the dual-income families' future with its changing eating patterns. Catering is a good business for the restaurateur, because it uses personal care and service as its base. For the restaurant operator, this will marshall resources in an efficient and cost effective way.

There are some assumptions that you should be aware of if you want to enter the world of catering:

1) Cooking:

Many catering businesses start because one person says to another at a dinner party, "Wow, this is wonderful. You ought to go into catering."

2) Slow times:

Catering, in most instances, is busy when restaurants are busy. With the exception of unusual holiday periods like Christmas, where caterers are even busier than restaurants, the demand for resources is concurrent.

3) Complementary Skills:

The new caterer needs to understand that work scope is vastly different. Service personnel have to drive trucks, carry tables, wash 
dishes, load vehicles, wear work gloves, and then change clothes and serve with all the grace and aplomb of their restaurant counterparts. As a restaurant operator, you can be successful if you are aware of these differences and allow for them.

Most caterers have:

1) Away games,

A caterer can describe off-premise catering as playing all "away" games, whereas restaurateurs play "home" games. This is an obvious allusion to the fact that a caterer always has a surprise in store at a "foreign" location.

2) Uncontrolled spaces

The caterer works in a different space for each function.

3) Secondary food handling: Preparation methods vary greatly between the cooking and serving of food that goes on in a restaurant and the unpacking/ cooking/ chilling/packing/loading/unloading/reheating/ serving of food that a caterer needs to be concerned with.

4) To provide variety 
The continual demand for something new from the vast catering market is good for caterers, and more difficult for restaurants with heavy capital investments in specific themes. The foodservice world is changing, responding to the customers' growing demand for something constantly different.

5) Large swings in the workforce Even though restaurants have no picnic in terms of labor turnover, the large swings in needs for catering service personnel are its identifying feature.

6) Mobile equipment

In catering, an empty space becomes a kitchen, a buffet becomes a room full of tables, the equipment for which has to be packed, moved from one location to another and set up all in the space of a few hours.

Far from dampening enthusiasm, that you potential caterers-you who are looking for ways to expand your restaurant's profit margin by going into catering, or you who are being pulled into the catering business by demand can take a deep breath, and ask yourselves some questions.

1) Above all else, do your customers trust you? The caterers face a new dimension. The customer from your restaurant is now the host in 
his own home, which creates a different set of emotional responses.

2) Does your company have the genuine capacity to care?

Caterers are not solely in the food business-they are also in the personnel care business. The caterer's caring manner can be as important to the mother of the bride as the quality of the wedding cake.

3) Do you have a clear reputation?

The social catering--for weddings, funerals, bar mitzvahs, and other rites-of-passage events--is chosen with care by the consumer. A good reputation takes time to build. Even if you are new in the business, spend time networking and generating objective feedback that will help your business by helping new customers hear about you through their social grapevine. They say that one satisfied customer can generate nine potential new buyers.

4) Does your business have a personality that distinguishes it from all the others in the catering business?

One caterer in New York uses pink and black uniforms with pink bow ties for service personnel. 
A caterer in Atlanta uses a lucite box with bananas inside as their unique signature at every party

These, perhaps, are just symbols, but they carry the implication of a distinct personality behind the scenes. Even by only creating a knowing smile on a customer's face, the caterer has left his $\operatorname{mark} \cdot{ }^{10}$

The Changing Trends of the Catering Business.

The catering industry is particularly vulnerable to changes in the equal pay and sex discrimination laws because of the high number of woman employees. So several recent decisions will have considerable impact and could result in major changes in the industry. ${ }^{11}$

The Equal Value Regulations (1982) introduced the concept of equal pay for work of equal value and so allowed comparisons between different types of work. Comparison can even be made with workers employed by other companies so long as they work in the same establishment and the two employers are associated and are in the same group of companies.

${ }^{10}$ Jay Tradewel1, "The Successful Route to Catering," Restaurant Hospitality, (January 1987), p. 72.

"Olga Aikin, "Value of work is the key," Industrial Cater, (November/December 1985), p. 17. 
So where the catering is "in house" the risk of claims is great. But contract catering staff can only claim comparison with other workers in the same establishment when their employer is in the same group of companies. It is also possible for staff to seek comparison with workers at different establishments, but only when the comparitor workers are employed by the same employer and on common terms and conditions.

D. The projection to the year 2000 in the Catering Business

1. Changing Technology

The technological invention or innovation will have a direct effect on the catering industry.

The four main groups where innovation will take place are enzyme technology, genetic engineering, miniaturization and microprocessors.

To sum up the likely impact of technological change:

1) Food production and food processing are likely to become relatively cheaper, certainly in the 1990s.

2) Food preparation and cooking are likely to become more flexible and simple.

3) The catering industry will have the facility for improved information at its disposal, provided it knows what information it wants and how to use it. 
4) The consumer will also have the facility of more reliable and relevant information.

5) Conventional sources of energy are likely to become scarce but man will develop an alternative. ${ }^{12}$

2. The Opportunities for the Catering Industry.

The market opportunity for the catering industry certainly up to $1985 / 87$ and possibly up to 1990 will be excellent.

Eating habits are changing. The two great demand sectors in a period of rising standard of living are:

1) education, to ensure that one is with the leaders rather than the laggards; and

2) health, to ensure that one can enjoy affluence for as long as possible.

The future could be very profitable for hospitality industry, but it will require understanding, courage and resourcefulness to accept the challenge and to convert it into increasingly profitable operations.

The catering is fun, challenging, exhausting, demanding, and rewarding. You will have a great deal of success if you understand that the only common denominator between a good caterer and a good catering business.

${ }^{12}$ George Glew, op. Cit., pp. 41-42. 


\section{E. Employee Hiring}

The development of good hiring programs in the catering business is ultimately for the aim of, first, helping management understanding the magnitude of problems, and second, for the purpose of helping management find out what it can do about the phenomenon.

Hiring appropriate people for a position is a crucial task since organizational effectiveness depends largely on the skills and abilities of the employees. Employee hiring is a part of the larger, overall system of personnel administration, which also includes training and career development, employee-management relations, classification and pay, employee benefits and services, promotion, and handling personnel problems.

"Employment of workers is a major personnel function. How it is done is most important in creating and maintaining good employer-employee relations." 13

An importance of personnel selection, as offered by Sir Miles Thomas, is stated as follows:

To spend a lot of money and time choosing a machine of which the average working life is, say, ten years, and little of either on selecting men and women who

${ }^{13}$ Russel F. Moore, AMA Management Handbook, (New York, New York: American Management Association, Inc.), 1970. 
may be with the firm for forty years is shortsighted, to say the least, or industry and commerce. ${ }^{14}$

Success in hiring is a major determinant of employee effectiveness. In contrast, unsuccessful hiring programs can be extremely costly detriments to an organization. And when we find employees to fill staff vacancies we have to consider the costs of hiring an inappropriate person in terms of productivity and/or morale. The we can consider the costs in terms of dollars when a hiring effort has failed and one must begin the selection process another time.

\section{F. Employee Hiring Programs and Steps}

The essence of effective employee hiring lies in making a prediction about the future job performance of applicants for a given position. But such predictions are difficult, partly because only a limited amount of information can be gathered in the hiring process, and because important characteristics of job applicants are hard to measure accurately. ${ }^{15}$

An inaccurate selection decision results not only in costs to recruit, train, and compensate an incompetent em-

${ }^{14}$ Peter C. Morea, Guidance, Selection and Training, (Boston, MA: Routledge \& Kegan Paul Ltd.), 1972, p. 181.

${ }^{15}$ Robert D. Gatewood, and Hubert S. Feild, "A Personal Selection Program for Small Business," Journal of Small Business Management (October 1987), p. 17. 
ployee, but also in the cost of repeating these steps until an acceptable employee is found. ${ }^{16}$

Another study concluded that "... the recruitment and selection strategies used in business were imaginative. The interview and application blank accounted for 90 percent of the most frequently used selection techniques."17

The typical sequence of action necessary for successful hiring is as follows:

1. Determining Needs

When a vacancy occurs, the natural tendency is to rush to fill the position as quickly as possible. However, by doing this, the manager misses an excellent opportunity for reevaluating the position and its contribution to the organization. In order to be successful, an organization must be able to adapt to a constantly changing environment. This must be recognized in the hiring process in order to avoid bringing in someone with yesterday's skills to do tomorrow's job. ${ }^{18}$

The first step is to take a close look at the job, determine what changes need to be made and decide what skills,

${ }^{16}$ Robert $J$. Solomon, "Using the Interview in Small Business," Journal of Small Business Management (October $1984)$, p. 22 .

${ }^{17}$ Glenn M. MCEvoy, "small Business Personnel Practices," Journal of Small Business Management (October 1984), pp. $1-8$.

${ }^{18}$ Lynn Biscott, "Effective Recruitment and Selection," Canadian Manager (Spring 1986), p. 26. 
abilities, and attributes the new incumbent must have. This will provide a framework for evaluating applicants for the position. ${ }^{19}$

2. Develop a Meaningful Job Description, Specification and Analysis

Someone on the staff should first take the time to write a complete job description as a preliminary step.

The job description should consist of two separate lists. The first ought to specify tasks the employee will be required to do, results you expect him or her to achieve, and the opportunity for advancement. Where pertinent, this list should also include information about working conditions and hours, required travel or overtime, social obligations that go with the job, salary, fringe benefits, and perquisites. ${ }^{20}$

The second list should focus on education, specific skills, experience, and personality traits a person must have to do the job well. ${ }^{21}$

When the job vacancy is occurred, we pull the old job specifications from the files and review them. Usually the manager plays a part of a job specialist. He changes some

${ }^{19}$ Ibid. , p. 26.

20"How to Find New Employees Quickly and Efficiently," profit - Building strategies for Business Owners, (July 1987), p. 17 .

${ }^{21}$ Ibid., p. 17. 
of the experience needed to fit what he thinks would be useful at this time. But unfortunately, these decisions are based on his unsubstantiated concept of the job.

A job analysis is a systematic way of identifying the most important aspects of a job, such as the activities performed, tools and equipment used, and the physical working conditions. In most small businesses, this type of information is gathered through job analysis interviews with the individuals who are most closely associated with the job. Analysis of activities performed involves developing task statements to describe every task that is critical to successful performance on that job.

Task statements are written so that each shows:

1) What the worker does, as described by a specific action verb which introduces the task statement;

2) with (or for) whom or for what purpose the action is performed;

3) what the product, purpose, or expected outcome of the action will be; and

4) what materials, tools, procedures, or equipment are used to perform the task. ${ }^{22}$

${ }^{22}$ Robert D. Gatewood, and Hubert S. Feild, "A Personal Selection Program for Small Business," Journal of Small Business Management (October 1987), p. 18. 
This information is essential for identifying the worker characteristics necessary to perform the job. A general description of responsibilities will not serve this purpose. ${ }^{23}$

After all tasks related to the job have been described in task statements, the next step is to identify those that are critical to job performance. This is usually done by having one or more individuals knowledgeable about the job, rate the tasks on two dimensions. One dimension is the amount of time spent on the task; the second is the importance of the task for the successful completion of the job. 24

3. Preparing to fill the position.

Some preliminary work is usually necessary once a vacancy has been determined as insurance against various difficulties otherwise likely to be encountered. First, any existing hiring system should be reviewed or, if nonexistent, could be initiated. Second, review the information contained in job descriptions, classifications and/or analyses wherein pertinent data is provided on tasks to be performed and personal specifications. Third, attempt to identify current information about the work environment that would further define personal specifications. For example,

\footnotetext{
${ }^{23}$ Ibid. , p. 18.

${ }^{24}$ Ibid., p. 18.
} 
long range needs of an organization may require certain kinds of training or experience. Then again existing relationships or personnel difficulties may demand certain adjustments and flexibilities of the candidate. ${ }^{25}$

4. Developing a hiring program and instrument.

Common sense and the weight of the evidence suggest that the quality of the steps taken in the selection process have a direct bearing on the quality of the selection decisions that are made. ${ }^{26}$

While most small businesses do not follow the recommended steps in selecting new employees, in most cases they could do so without spending a great deal of time or money. The recommended steps include (1) conducting a job analysis, (2) identifying worker characteristics necessary to perform the job tasks, and (3) developing selection devices that measure these characteristics. 27

In many articles and books about employee selection, a fourth step is a recommended: validation of the selection program. In most cases, validation requires statistical

${ }^{25}$ Robert L. Brownfield and Warren $R$. Jones, Recruitment and orientation, (Atlanta, GA: U.S. Government Printing Office), 1985 , p. 2 .

${ }^{26}$ Robert M. Guion, "Recruitment, Selection, and Job Placement," Handbook of Industrial and Organizational Psychology, ed. M. Dunnette (Chicago: Rand McNally College Publishing Co.), 1976, p. 777.

${ }^{27}$ Robert D. Gatewood, and Hubert S. Feild, "A personal Selection Program for Small Business," Journal of Sma11 Business Management (October 1987), p. 17. 
analyses of the data used, a step most small business owner/managers would find too difficult or time consuming. However, careful attention to the first three steps can serve as the basis for another type of validation known as content validation. Content validation can be useful in evaluating the fairness and adequacy of the selection program and has been judged to be an adequate defense in some cases of alleged discrimination in hiring. ${ }^{28}$

An important, fundamental principle in developing selection instruments is that of "behavioral consistency."29

This principle states that there should be a direct correspondence between the information collected by selection instruments and critical job tasks. This correspondence exists if selection instruments collect information about how job applicants have performed activities that are similar to the previously identified critical job tasks. ${ }^{30}$

Three types of hiring instruments are useful for employee hiring in business including catering business in the South Florida area: training and experience forms, interviews, and work sample tests.

${ }^{28}$ Ibid. , p. 18 .

${ }^{29}$ Paul Wernimont and John Campbell, "Signs, Samples, and Criteria," Journal of Applied Psychology, Vol. 52, (1968), p. 372 .

${ }^{30}$ Robert D. Gatewood and Hubert S. Feild, op. cit., p. 


\section{Training and Experience Form}

A Training and Experience Form is designed to solve the problem of inadequate data on applicants by enabling one to collect specific, job-related information. A typical form (see Table I) incorporates the following:

1) A listing of critical job tasks.

2) A means for applicants to indicate their training and experience with these job tasks.

3) A basis for scoring applicants' training and experience.

The developing of such a form begins with the critical tasks identified in the job analysis. As shown in Table I'; these tasks are listed separately. For each one, applicants indicate work experiences, training, or related activities that are similar to the task. In addition, the applicant is also asked to list the organization at which the training or experience took place and when this occurred. ${ }^{31}$ Such information can be scored in a variety of ways. One way is simply to give each relevant response a score of one; Non-relevant or "no" responses are scored zero. Another alternative is to weight each of the critical job tasks according to its importance to the job as determined by ratings in the job analysis. An applicant's total score will then reflect the number of experiences he or she has had

${ }^{31}$ Robert D. Gatewood, and Hubert S. Feild, op. cit., p. 20. 
which are similar to critical job tasks. Thus, higher scores indicate better qualified applicants. 
Table $I^{32}$

\begin{tabular}{|c|}
\hline $\begin{array}{c}\text { AN EXAMPLE OF A TRAINING AND EXPERIENCE FORM FOR } \\
\text { THE JOB OF CONVENIENCE STORE MANAGER }\end{array}$ \\
\hline $\begin{array}{l}\text { Listed below are some important job tasks performed by a } \\
\text { Convenience store Manager. Read each of the tasks. If you } \\
\text { have had experience or training in performing a related } \\
\text { task, check the box marked "Yes." If you have not, then } \\
\text { check the box marked "No." For the task(s) marked "Yes," } \\
\text { please describe your experience and training. All of your } \\
\text { responses are subject to review and verification. }\end{array}$ \\
\hline $\begin{array}{l}\text { Have you had previous } \\
\text { experience or training } \\
\text { with this task? }\end{array}$ \\
\hline $\begin{array}{l}\text { 1. Trains new employees in } \\
\text { operating a cash register, } \\
\text { keeping inventory records, and } \\
\text { stocking of shelves. }\end{array}$ \\
\hline
\end{tabular}

EXPERIENCE

Employer:

Employment dates: Describe Your Expe:ience With This Task:
TRA IN ING

Formal Coursework and location

Training Programs Attended and Location:

On-the-job Training:

$\begin{array}{ll}\text { Yes } & \text { No } \\ {[1} & {[1]}\end{array}$

$\begin{array}{ll}\text { Yes } & \text { No } \\ {[]} & {[]}\end{array}$
2. Inspects and performs routine maintenance on coolers, food preparation equipment, and Slushie machine.

3. Complies daily records on dollar volume of sales of food, alcohol, and gas for each shift and each clerk.

Source: Jcurnal of Sma I Business Management (October 1987). 


\section{Interview}

Applicants with the highest scores on the Training and Experience Form who also possess appropriate background characteristics are asked to participate in the second step in the selection program--the interview.

The key factor at this stage is to design an interview that is effective in measuring important characteristics of applicants. The most important features to incorporate into the interview design are:

1) Assessment of only a small number of applicant characteristics.

2) A semi-structured format. (Predetermine major questions to be asked).

3) Use of job-related questions only.

4) Use of more than one question for each applicant characteristic.

5) Ratings of each applicant on each of the characteristics assessed in the interview. ${ }^{33}$

The heart of the recruitment process is the interview of a potential employee. As one expert wrote:

of all the methods used to appraise job qualifications, the interview is the oldest and the most widely practiced. The interview is the principal 
instrument of selection because it is used not only to obtain information from an applicant but to give him the information he needs to establish an interest in the job and to motivate him to persist in the pursuance of his application. ${ }^{34}$

An employment interview typically refers to a single event for the purpose of screening, evaluating and selecting the most appropriate candidate. However, a series of interviews may be conducted in the recruitment system by various individuals to not only screen, evaluate and select but to also pre-screen candidates, administer aptitude tests and conduct personality assessments. ${ }^{35}$

When done properly, the interview is an excellent screening device. It is legally possible to inquire about past performance, interests, and preferences in great depth as long as the information you seek has some relationship to the work the person will perform. ${ }^{36}$ This interview should

${ }^{34}$ Roger H. Hawk, The Recruitment Function, (New York, New York: American Management Association, Inc.), 1967.

${ }^{35}$ Rnhert L. Brownfield and Warren R. Jones, 1985, op. cit., F. 3.

${ }^{36}$ John J. Herring, "Establishing an integrated Employee Recruiting System," Personnel (July 1986), p. 51. 
be conducted in order to obtain as much information as possible about the candidate's interests and abilities. ${ }^{37}$

The effectiveness of a structured employment interview depends on an interviewer's skills in the following five areas:

1) Planning. Planning and preparation are crucial ingredients for focusing on the right dimensions during an interviewer's limited time with applicants.

2) Information gathering. The single most important ingredient for a successful interview is an interviewer's skills in eliciting enough of the right kind of information from applicants.

3) Evaluating. The evaluation aspect of the interview process places the greatest demands on an interviewer's analytical skills.

4) Decision making. After several applicants have been evaluated for a specific position, an interviewer needs to make a decision about the person most likely to succeed.

5) Documenting. From both a business and legal perspective, it is important for an interviewer to document interview questions, 
applicant responses, and evaluations in key areas. ${ }^{38}$

The interview itself also involves three steps:

1) Create a relaxed, non-stressful interview atmosphere. The following techniques can help reduce the stress experienced by most applicants during an interview:

a. Conduct the interview in a pleasant, comfortable room free of distractions.

b. Allow enough time to complete the interviews.

c. Establish rapport with applicants and avoid artificial, formal behavior.

d. Describe the interview process to applicants. One strategy to help minimize anxiety involves giving applicants the list of interview questions about a half hour before the interview.

2) Obtain job-related information from applicants by asking the questions prepared for each essential competency.

a. Direct questions should represent the bulk of time spent with applicants. It Interviews," Personnel Journal (May 1986), pp. 91-92. 
is a good idea to ask the same questions (or similar questions) in the same order (or similar order) when conducting successive interviews for a position. b. The most important points to remember are to concentrate on listening, to avoid hasty conclusions and judgmental remarks, to continue probing in an area until sufficient information has been gathered, and to determine the reasons behind reported behavior.

c. Note-taking and tape-recording should be as unobtrusive as possible and should not interfere with the flow of the discussion.

3) Describe the job and organization to applicants.

a. One of the major objectives of the employment interview is to provide a realistic job preview so applicants can determine if they are interested.

b. Pay particular attention to explaining the position's duties, responsibilities and relationship to the overall organization. 
c. It is helpful to use a job description, an organization chart, company brochures, and applicable policies and procedures when describing the job.

d. Certain advantages can be emphasized to attract promising applicants, but misrepresenting the job is illegal.

e. Avoid telling applicants too much about the job early in the interview to discourage "socially desirable" responses. 39

Recognizing the purposes of each participant in an employment interview setting helps to understand the motivational environment and the direction of the dialogue. However, proper preparation and practice in techniques are exceptionally important prerequisites to a successful interview and should be given due consideration.

Some common techniques used to interview for employment have been characterized as follows:

1) The "tough-guy" interview.

The interviewer establishes a one way communication, except for a series of questions about qualification, and rarely

${ }^{39}$ Ibid., pp. 92-93. 
looks directly at the candidate. The parting remark is typically, "we will let you know."

2) The intellectual discourse.

The interviewer asks questions designed to explore the depth and breadth of interest exhibited by the applicant.

3) The "client-centered" counseling interview. The interviewer radiates warmth and permissiveness, asks broad questions, and encourages the applicant to talk freely and extensively.

4) The brotherhood ritual

The interviewer searches for old school ties and mutual acquaintances. ${ }^{40}$

Most interviewing techniques are actually variations or combinations of different techniques and each possesses some degree of uniqueness. The most useful strategy is to simply "be yourself:" be open and honest; never make promises you are unable to keep; and establish a straightforward two-way communication.

An interviewer talking to an applicant

is truly a blind person trying to learn

what an elephant is like from examining

${ }^{40}$ Robert $L$. Brownfield and Warren R. Jones, 1985 , op. cit., p. 5 . 
only one part of the beast. Yet interviewing is the preferred method-often the sole means--for selecting job candidates. ${ }^{41}$

The other important thing to remember about the employment interview is that it is not a conversation. Unlike a conversation, the interview is a methodical process for obtaining critical information to help make judgments about people's chance for success.

\section{Work Sample Tests}

In small businesses, personnel selection decisions are usually made after the applicant's interviews are completed. ${ }^{42}$ In many cases, however, the selection process can be greatly improved by adding a third step following the interview-administration of work sample tests to a few applicants who scored well in the previous two steps (Training and Experience Form, Interview) of the process.

Work sample tests are essentially replications of critical job tasks. If the applicant can successfully perform critical parts of the actual job, he or she is likely to be successful on the job as a whole. Work sample

${ }^{41}$ Lee Bowes, No One Need Apply, (Boston, MA: Harvard Business School Press), 1987, p. 81.

${ }^{42}$ Glenn M. MCEvoy, 1987, op. cit., p. 1. 
tests are often used to test applicants for clerical jobs. ${ }^{43}$ These tests can also be devised for many other jobs in business.

Work sample tests must be related to critical job tasks, and there must be a formal method of scoring the test. In almost all work sample tests, the applicant must either perform a set of job actions or produce a product. Scoring the test involves either the actions performed or the product produced. ${ }^{4}$ product scoring is usually used when there is clearly one, best way of performing the critical task. It is also used when a large number of different behaviors can lead to an acceptable product, and the product can be judged against a standard. In that case, the principal of "behavioral consistency" is adhered to. ${ }^{45}$

For many other jobs, the development of a work sample test is much simpler and less expensive.

5. Advertising

Advertising is defined as "the process which the action of calling something to the attention of the public, especially by paid announcements."

${ }^{43}$ Robert D. Gatewood and Hubert S. Feild, op. cit., p. 23.

${ }^{44}$ Ibid.

${ }^{45}$ Ibid. 
And the recruitment advertising might be defined as "the action of calling a job opening to the attention of potential employees, especially by paid announcements."

The placement of recruitment advertising implicitly acknowledges two things:

1) The job market in question is competitive; and

2) The company advertising hopes to gain an advantage over companies competing for the best candidates in the available labor pool.

Effective advertising can clearly provide that advantage by creating or reaffirming a positive corporate identity, pinpointing merits of employment at the company placing the advertisement, and appealing to each employee's pride in his or her talents. ${ }^{46}$

Employment advertising should be carefully considered before it is undertaken. Many companies tend to advertise before exhausting less expensive and, frequently, more effective methods. Employment advertising is deceptively expensive. So we must exercise care and judgment in writing the advertisement and selecting the publications for placement. 47

"4Gargaret Magnus, "Recruitment Advantages," Personnel Journal (August 1986), pp. 58-59.

${ }^{47}$ John J. Herring, 1986 , op. cit., p. 50. 
There are several ways to target an advertisement as follows:

1) Identify the positive aspects of the organization.

The organization's work environment, corporate culture, career opportunities, benefits and location are selling points. Capitalize on them to attract employees.

2) Use humor, but in a careful way. Humor can be the fastest way to address a perceived problem but humor is used so rarely--in all types of advertising--and it generally is not used well.

3) Appeal to potential employees' sense of pride.

An effective way to catch the attention and interest of job candidates is to appeal to their sense of pride in themselves and their profession.

4) Know what motivates the audience.

We must consider an ideal candidate. What motivates this person? What benefits and rewards is he or she looking for? What sort of working environment, career opportunities and level of job satisfaction? Once we have answered these questions, we have some of the 
guidelines for developing recruitment advertisement.

5) Use recruitment brochures.

Recruitment brochures are used at job and career fairs to educate potential employees. Brochures have an important role and act as a "sales-person" for the organization. The brochure should contain all the information of a recruitment advertisement and more. It should include information about the organization, its benefits, the types of jobs available, the career development programs and how to apply. Above all, recruitment brochures should be functional. They should serve their purpose, i.e., to provide information about the jobs the organization is hiring for.

6) Use employees as resources.

When hiring new employees, it makes a certain amount of sense to take advantage of employees already on the job. Testimonials are an effective means of doing just that. Testimonials can

a) Create a corporate identity through the job goals and experiences of actual employees. 
b) Create credibility.

c) Establish track record and provide concrete examples of the organization.

d) Show real people working in the organization.

e) Prove that people are our must important asset.

The use of employees in recruiting advertising has grown beyond just traditional testimonials, as companies enjoy the many advantages of using their primary resource-their work force--to recruit new employees. ${ }^{48}$ Using employees in advertising also tends to bond them to the company's recruiting intents. The advertisements implicitly inspire potential employees to aspire to greatness and show how employees have fulfilled their own aspirations. ${ }^{49}$

A well-targeted advertising program will produce prospects, although this is more effective for lower-range positions. Advertising results in a shotgun pattern, however, with much time spent reading through and screening out inappropriate resumes to find a few qualified candidates. ${ }^{50}$

${ }^{48}$ Bob Martin, "Recruitment Adventures," Personnel Journal (August 1987), p. 48.

${ }^{49}$ Ibid.

${ }^{50}$ Bruce S. Algar, "How to Hire in a Hurry: Meet Increased Demands for Personnel, "Personnel Journal (September 1986), p. 89. 
6. Finding Suitable Applicants

Many different sources of recruitment are available to the manager. Qualified applicants can also be found by: placing an advertisement in a newspaper; internal job postings; unsolicited resumes or applications; contacts with local colleges, universities, and professional associations; advertisements in professional journals or newsletters; and private employment agencies, etc. Internal job posting encourages career development and growth within the organization. If you are advertising for a specialized professional position, you need to choose a paper with much wider distribution (eg. a large national daily) than you would for a clerical position, where an advertisement in community newspaper might be sufficient.

\section{Collecting and Analyzing Resume \& Application}

There are three major ways of collecting information about an applicant: the resume, the personal interview, and the reference check. A quick overview of the resume will tell you if the applicant has the background and experience you are seeking. If so, read the resume thoroughly, trying to construct a picture of the applicant.

The format and style of the resume can be important, depending on the nature of the job. If you are hiring for a position where good skills in communication and written presentation are important, then the resume should be 
evaluated with this in mind. ${ }^{51}$ Look for evidence of career progression and accomplishment on the job throughout the resume. No matter what position you are hiring for, you will want someone who has the ability to grow and develop in the job and to make a contribution to the organization as a whole. 52

When screening resumes, look for the following:

1) Does applicant meet the basic specification? You do not need to waste time calling candidates who fail to meet the key requirements for the job.

2) Look for omissions.

Many resumes omit dates of employment. This may be done to hide periods of unemployment or to leave an impression of having more or better experience than really achieved. One way to overcome this is to have all applicants complete an application form.

3) Look for inconsistencies.

An applicant may claim heavy background in one area, yet the companies for whom he or she worked may not be involved in that area.

4) Look for progress.

${ }^{51}$ Lynn Biscott, 1986, op. cit., p. 27.

${ }^{52}$ Ibid. 
You have to look what the candidate has made appropriate progress in terms of advancement and earnings for the amount of years in the work force. Also you can compare the backgrounds of candidates as they relate to the job specs and then as they relate to each other.

\section{Ask Questions to Uncover True Qualifications}

Once you have made the applicant feel at ease by a friendly greeting and a few comments on noncontroversial aspects of the applicant's background, you can ask "openended questions": "Tell me about your experience with the XYZ Company": "What background do you have in sales analysis?" "Describe your most recent project." On the basis of the responses received, focus on key aspects of the candidate's background in that area and ask specific questions on details of what was done and accomplished. ${ }^{53}$

By asking about specific facets of the project rather than just accepting the statement, the interviewer will obtain a clear view of actual experience rather than the usual generalizations that are so often elicited in a job interview and it will help identify the real accomplishment of the candidate.

Identifying the Applicant Characteristics

53"Recruiting: Five Steps to Better Hiring," Managers Magazine (July 1987), p. 23. 
The next step is, in some ways, the most difficult one to implement, because it runs counter to commonly held assumptions about personnel selection. Very often, applicants are evaluated using criteria such as academic degrees or courses and previous work experience as reflected in their job titles.

The assumption that an applicant will perform well on the job if he or she has the desired education and/or experience is justified only when the education or experience is very similar to the activities identified in the job tasks. ${ }^{54}$

It is more useful to identify the specific characteristics of workers, commonly referred to as knowledge and skills, that are important to job performance. Specification of the knowledge and skills necessary to perform critical jobs can best be done by those familiar with the job. So the identification of the types of knowledge and skills are required.

Some guidelines for describing knowledge and skill requirements are:

1) Statements should be written so that they clearly describe both the kind of knowledge or skill required and the degree or level of

${ }^{54}$ Robert D. Gatewood and Hubert s. Feild, op. cit., pp. $18-19$. 
each that is needed for successful performance.

2) Statements should be written to reflect the highest level of competence that is required for the job.

3) Specific statements are preferable to general ones.

Once the knowledge and skills required for successful job performance have been identified, the next step is to evaluate the applicant characteristics.

Evaluating the Applicant Characteristics

You hire not only a person's job skills, but also the personal characteristics the individual brings to the job. A person with good looks, charm, a gift of gab, and a pleasant way makes such a good impression on you that you may be overly influenced by this veneer. To determine the true personality of the applicant, you must look beneath the surface. By using "situational questions," true personality traits can often be uncovered. A situational question is one in which the candidate is asked to respond on how he or she handled delicate problems in the past or how hypothetical situations might be handled. ${ }^{55}$

From the response, you can determine the candidate's integrity, tact and attitude, etc.

55"Recruiting: Five Steps to Better Hiring," Managers Magazine (July 1987), p. 24. 


\section{Verifying}

Whenever possible, you should contact the former employers of applicants in whom you have interest to verify that what they have told you is correct. More and more companies are reluctant to give information about former employees to others, but it is worth the effort to try.

One way to overcome resistance to giving information is to emphasize that you would like to verify information rather than ask for information.

7. Making a Selection or Rejection

Once all the information has been gathered, you should decide whether or not the candidate should be hired. If references have not been checked previously, this should be completed before any offer is extended. An offer of employment should be made verbally to the chosen candidate, followed by a letter confirming all pertinent details. spelling out terms and conditions of employment at this point in detail can avoid any misunderstandings later.

Selecting quality people does pay off: for the company, the employees, and the managers. The process described in Table II affects significantly the bottom line as it relates to the performance of people in an organization. An analysis of the job demands and work samples, both in an interview situation and in an assessment center, provides data which, when used properly, can enhance significantly selection decisions. On the other side, the analysis 
provides the applicant with a realistic preview of the job: an outcome of the process which ultimately may affect terminations.

Once a decision is made to either hire or reject a candidate, it is best to follow a set procedure. If the decision is to make an offer, the hiring supervisor should phone the candidate and make the offer on the telephone. This will permit the candidate to clarify any questions about the job's technical aspects. The supervisor should conclude the conversation by indicating that an offer letter outlining the details of the job offer will follow. ${ }^{56}$

${ }^{56} \mathrm{John}$ J. Herring, 1986, op. Cit., pp. 51-52. 
Table II: The Selection Process ${ }^{57}$

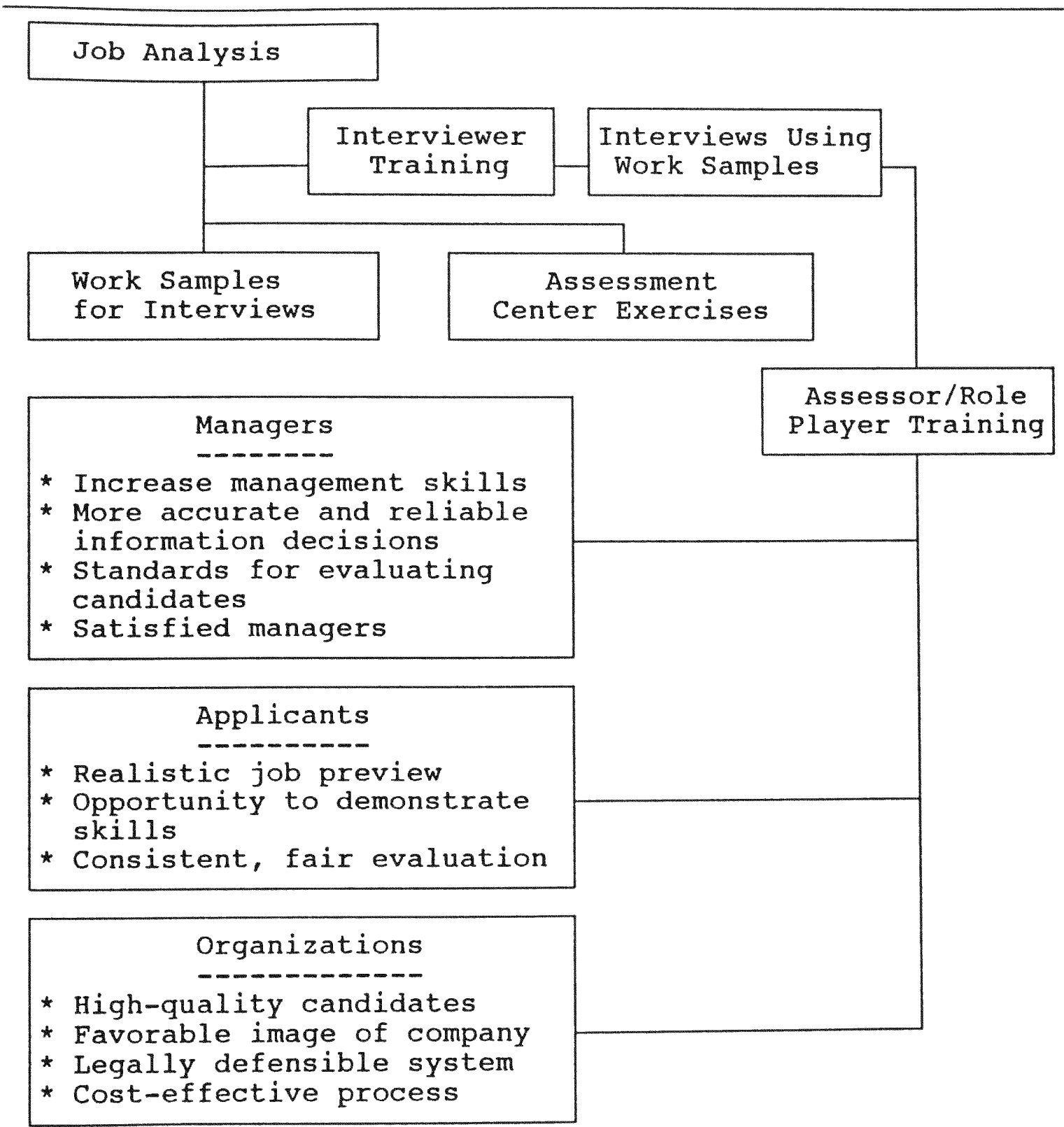

This figure is taken from the Performance-Based Interviewing brochure published by Assessment Designs, International

Source: Training \& Development Journal (August 1986).

${ }^{57}$ Lynn Slavenski, "Matching people to the job," Training \& Development Journal (August 1986), p. 57. 
If the candidate is rejected, the decision should be communicated by telephone or in writing as soon as possible, including the reason for the turndown if appropriate. This is a very delicate and serious message; how it is treated says volumes about the company. Always think it through carefully and be aware of the legal considerations surrounding the employment process before you respond. ${ }^{58}$

Once the chosen candidate has accepted the position, you have to remember to respond to the unsuccessful applicants. It is important that they too are left with a favorable impression of your company--they may one day be your customers.

8. Orientation

This is an important and often-neglected step in the hiring process. There is a tendency for managers to feel that, once the new person is hired, the job is over and you can all get back to business. However, to help ensure a successful start for the new employee, a well-planned orientation is important. This is relatively simple if selection was made from within the organization but requires special effort if selection came from outside. Hopefully, the recruitment process has been conducted to this point in a manner that has made the candidate feel enthused and

${ }^{58}$ John J. Herring, 1986 , op. cit., p. 52. 
prepared for his new tasks. This will make an orientation procedure much easier to design and implement.

An orientation process should have the personal attention of the supervisor and he should carefully select those who are to assist in the orientation as well as insist that a planned program be followed. Orientation should be thorough and continuous. In fact, orientation is inseparable from training and is really the beginning of onthe-job training and career development. 59

Many companies use a checklist for the orientation process. A checklist is helpful in assuring that nothing important is overlooked. Sample checklists can be found in the various personnel service manuals of such organizations as the Bureau of National Affairs or Commerce Clearing House. 60

In an orientation process, the employee should be given a copy of his or her job description, and an employee handbook, where available. In order to familiarize the new employee with the organization, pertinent books or materials such as an annual report should be made available. You have to provide an opportunity for the employee to review the personnel policy manual and any applicable departmental policies. Many problems can be avoided by making sure that

${ }^{59}$ Robert L. Brownfield and Warren R. Jones, 1985 , op. cit., p. 6 .

${ }^{60} \mathrm{John} \mathrm{J}$. Herring, 1986 , op. cit., p. 52 . 
the new employee is aware of rules and procedures as soon as possible.

A well planned orientation should be prepared for every new employee and should include the following:

1) The job:

a. Work site

b. Introduction to co-workers

c. Instructions on who to turn to for answers to questions and problems

d. Review of equipment items

e. Written technical procedures and guidelines available

f. Procedures for securing needed supply items

g. Uniforms

2) Facilities:

a. Parking

b. Coffee breaks

c. Eating places

d. Restrooms

e. Lockers

f. Library

3) Policies:
a. Tardiness
b. Annual leave
c. Sick leave 
d. Vacations
e. Handling of emergency requests

4) Organization:

a. History of its parent organization

b. "Rituals" observed

5) Safety regulations and procedures

6) Personnel benefits and services:

a. Medical examinations

b. Health and hospitalization insurance

c. Group life insurance

d. Retirement

e. Credit Union ${ }^{61}$

Effective human resource management depends to a considerable degree on setting the stage for success throughout the recruitment process. Following the steps above will ensure that both you and the new employee are well-prepared for a positive beginning.

${ }^{61}$ Robert L. Brownfield and warren R. Jones, 1985, op. cit., pp. 6-8. 
III. THE DATA AND THE TREATMENT OF THE DATA

A. The Data

The data of this research are of two kinds: primary data and secondary data. The nature of these two types of data will be given briefly below.

The Primary Data. The responses to the questionnaire sent to the managers and employees of the selected catering businesses in the South Florida area are one type of primary data. The information gathered from personal interviews with catering business managers and employees under study are another type of primary data.

The Secondary Data. The published studies and texts and the unpublished dissertations dealing with employee hiring programs and methods are one type of secondary data. Library research including information gathered from current periodicals, industry journals, published articles, and books are another type of secondary data.

B. The Criteria Governing the Admissibility of the Data

Only responses from the catering business managers and employees of the south Florida area will be used in this study.

Interviews and surveys are limited to those related to employee hiring programs within the catering business in the South Florida area. Information gathered from published 
works are limited to those which appeared in a reputable magazine, journal, and newspaper.

C. The Research Methodology

The descriptive survey method will be used for the gathering of the primary data in this study. Since this study involves personal interviews and questionnaires as a method of collecting proper information, it falls under the descriptive survey method. It is a method that looks with intense accuracy at the phenomena of the moment and then describes precisely what the researcher sees. It is also called the normative survey, implying that whatever we observe at any one time is normal and under the same condition, could be observed at any time in the future.

According to paul D. Leedy, the salient characteristics of this survey method are:

1. The descriptive survey method deals with a situation that demands the technique of observation as the principal means of collecting the data.

2. The population for the study must be carefully chosen, clearly defined, and specifically delimited in order to set precise parameters for ensuring discreteness to the population.

3. Data in descriptive survey research are particularly susceptible to distortion through the introduction of bias into the research design. 
Particular attention should be given to safeguard the data from the influence of bias.

4. Although the descriptive survey method relies upon observation for the acquisition of the data, those data must then be organized and presented systematically so that valid and accurate conclusions may be drawn from them. ${ }^{62}$

In order to collect the needed primary data for the specific methodology, mail surveys and personal interviews will be best suited.

The descriptive survey method involves observing the population which falls within research parameters and recording what is observed for analysis. This analysis will give an insight to the proposed problems. Data must be presented systematically so that valid and accurate conclusions may be drawn.

The data calls for the solicitation of opinions of the managers and employees of the selected catering businesses in the South Florida area. To get their opinion, interviews must be conducted personally by the researcher within the shortest possible time.

By using interviews as a technique for gathering data, interviewees are being encouraged to be specific on various management attitudes, caused them to elaborate on important

${ }^{62}$ Paul D. Leedy, Practical Research, ed. 3, New York: Macmillan Publishing Co., Inc., 1985, p. 134. 
aspects and evaluate the effectiveness of a proposed employee hiring programs.

Using a questionnaire is another technique for collecting primary data. This questionnaire should be designed to fulfill a specific research objective. Aimless haphazard thinking and careless imprecise expression are the most commonplace faults in questionnaire construction. This lack of design and precision of expression may also account for the small return of questionnaires when these are sent to a given population. ${ }^{63}$ And a questionnaire must be built and quality-tested again and again for precision of expression, objectivity, relevance, suitability to the problem situation, and probability of favorable reception and return.

D. The Specific Treatment of Data for Problem

The problem. The problem is to determine the effectiveness of employee hiring programs in the catering business in the South Florida area.

The Data Needed. The data needed for the solving of this problem are the responses of those catering business managers and employees to the questionnaires concerning employee hiring programs.

The Location of the Data. The primary data will be located in the responses to the survey forms when completed 
by managers and employees of the catering business in the South Florida area.

The secondary data is located within the published texts, periodicals and journals at the library of Florida International University and some of the public libraries in the Miami area.

The Means of Obtaining the Data. The primary data will be obtained by means of personal interviews with, and questionnaires to, the managers and employees of the selected catering businesses in the South Florida area.

The secondary data will be obtained through library research from Florida International University and public libraries in the Miami area.

The Treatment of the Data.

How the Data Will Be Screened. The questionnaires returned will be screened to eliminate those where the respondent failed to answer all the questions.

How the Item Analysis will Be Made. The analysis of this study will involve identifying the factors affecting the development of effective employee hiring programs in the catering business in the South Florida area, and then properly organizing the responses, analyzing the data, and discussing the findings concerning these factors.

How the Data Will Be Interpreted. The response data will be summarized and tabulated and the implications indicated by the results will be used to provide an adequate 
interpretation of the hypothesis. The information derived from comparing the primary data and secondary data will help to determine the evaluation of the factors pertinent to the hypothesis made. 
IV. GENERAL PROCEDURE

A. The population of the study

The selected catering companies consisted of twenty hotels or catering companies operating catering services. The sample group consisted of 10 hotels which had catering departments and composed of 10 catering companies managing on-premise or off-premise services located in the south Florida area. One of the catering companies was temporarily closed at the time of research, therefore, the total number of the selected catering companies was nineteen.

B. Collection Procedure

The researcher telephoned or visited the sample catering companies to set up appointments with the managers in charge of handing the hiring program within their companies. As a result, fourteen questionnaires (Appendix) were given to the managers of the selected catering companies. The researcher mailed five questionnaires to the remaining five catering companies as he could not succeed in making appointments with the managers of those companies.

Interview. The researcher conducted interviews with the managers of catering companies in the Fall of 1988 and in the spring of 1989 . The researcher made visits to the hotels and catering companies to obtain as much information as possible regarding the importance of competent and ineffective employee hiring programs in the catering 
business.

The researcher followed the proper procedure of the questionnaires closely, tape recording and taking notes during each interview. Immediately following each interview, the researcher consolidated all information gathered.

Questionnaire. After the managers of the selected catering companies were interviewed, the questionnaires were prepared. Many of the chosen managers were not willing to cooperate, thus, another selection was made out to the representative group of directors and caterers. As a result, the questionnaires were answered. It was surprising that most of the managers agreed to cooperate. Seventeen questionnaires were returned, although some of the information requested was not provided. Question by question, the data was categorized. Activities that did not pertain to this particular categorization were set apart as separate techniques. After all the interviews were completed and the questionnaires answered, the information was standardized and consolidated. 
V. SURVEY RESULTS

The purpose of this research was to identify and analyze the effectiveness of employee hiring programs in the catering business.

In order to get the desired results aimed at this research, the questions on the questionnaire composed of the following interrelated areas:

1. General information

2. The sequence of proper employee hiring programs

3. Existing employee hiring methods

4. Hiring program evaluation

A. Questionnaire Findings

The results from those received responses are summarized as below:

$$
\begin{array}{lc}
\text { TABLE III } & \\
\text { Number of Catering Companies } & 8 \\
17 & 89.0 \\
2 & 11.0 \\
19 & 100.0
\end{array}
$$

Responded

No Response

Total

As mentioned before, the surveyed catering companies consisted of nineteen companies. As shown in Table III, seventeen catering companies responded to the questionnaire representing eighty-nine percent of the surveyed companies, while no response was ever received from the remaining two companies, eleven percent of the sample group. 
It would be interesting to note that 14 catering companies, an 82 percent of those who responded replied with a letter stating that there were no specific employee hiring programs in their catering department of their hotels or in their catering companies.

However, 18 percent of those who responded, representing just 5 catering companies, completed in full the questionnaire and stated that they do have such specific hiring programs. Indeed only this surprisingly small percentage does provide hiring programs for their managers in the catering departments or catering companies.

The following comparison would serve as a means to better understand the present situation in the surveyed catering companies:

\section{FIGURE 1.1}

Selected sample of 19 hotels or catering companies (100\%)

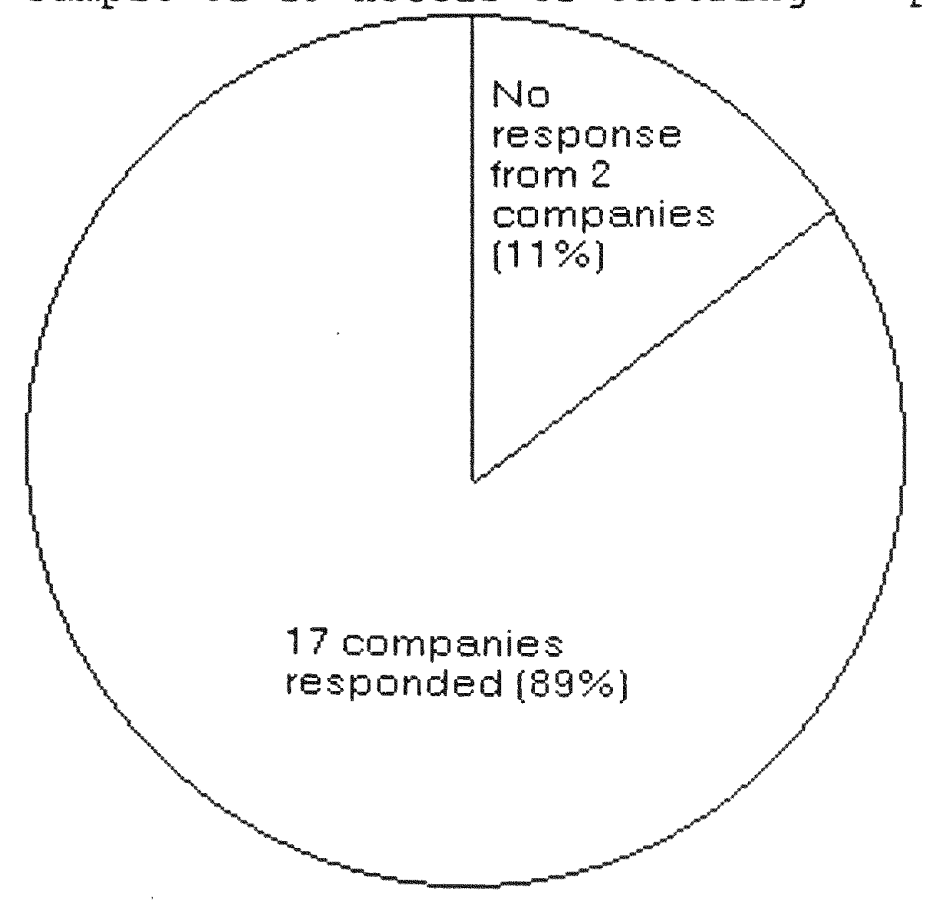


FIGURE 1.2

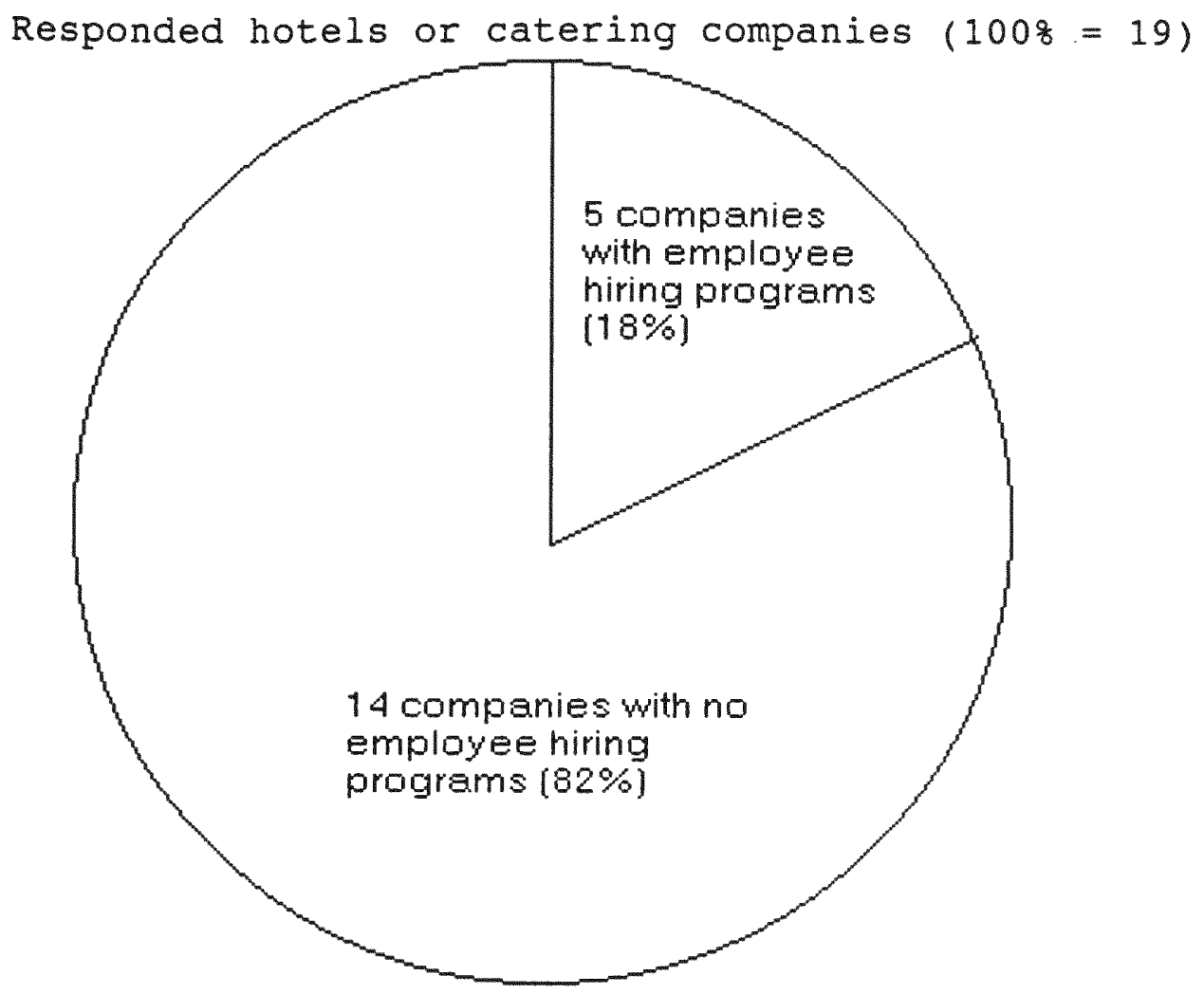

Because the researcher wanted to give a better perspective in the distribution of the number of employees among the selected catering companies, the means for the sample group of companies is presented as follows:

Number of employees

$$
\begin{aligned}
& 10-20 \\
& 20-30 \\
& 30-40 \\
& 40-\text { above }
\end{aligned}
$$

Number of companies 2

Mean $x=33$ employees 
FIGURE 2

Distribution chart of number of employees

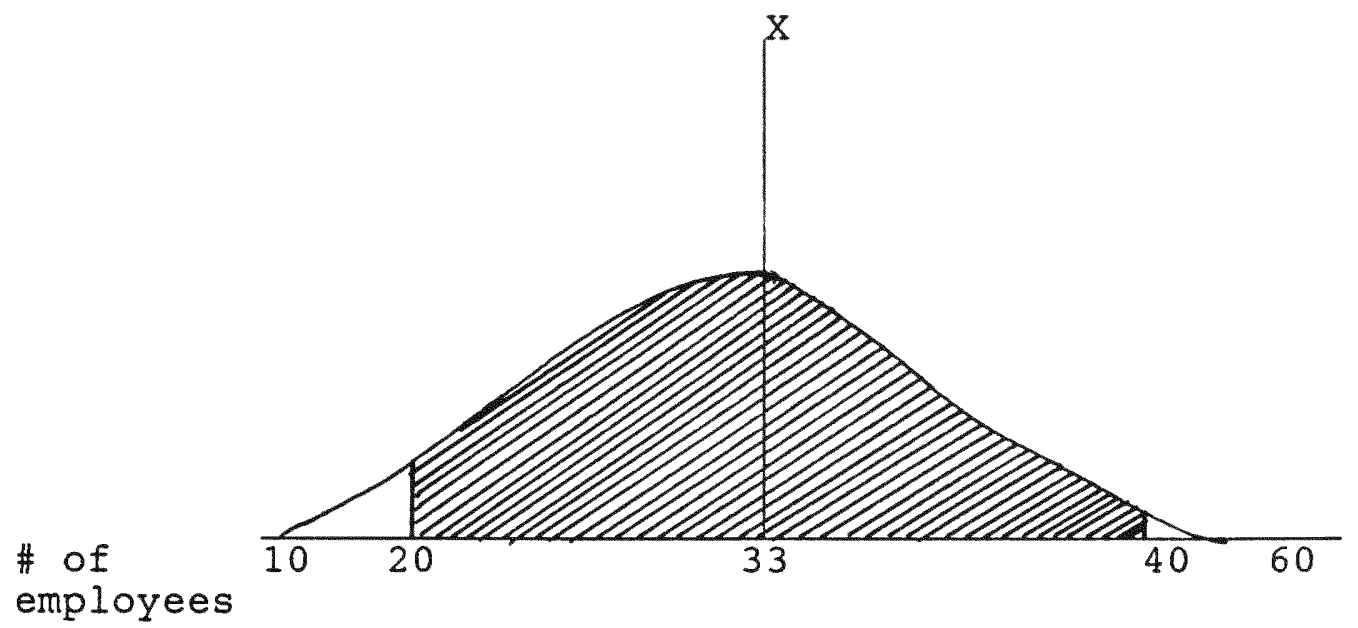

FIGURE 3

Frequency distribution of number of employees

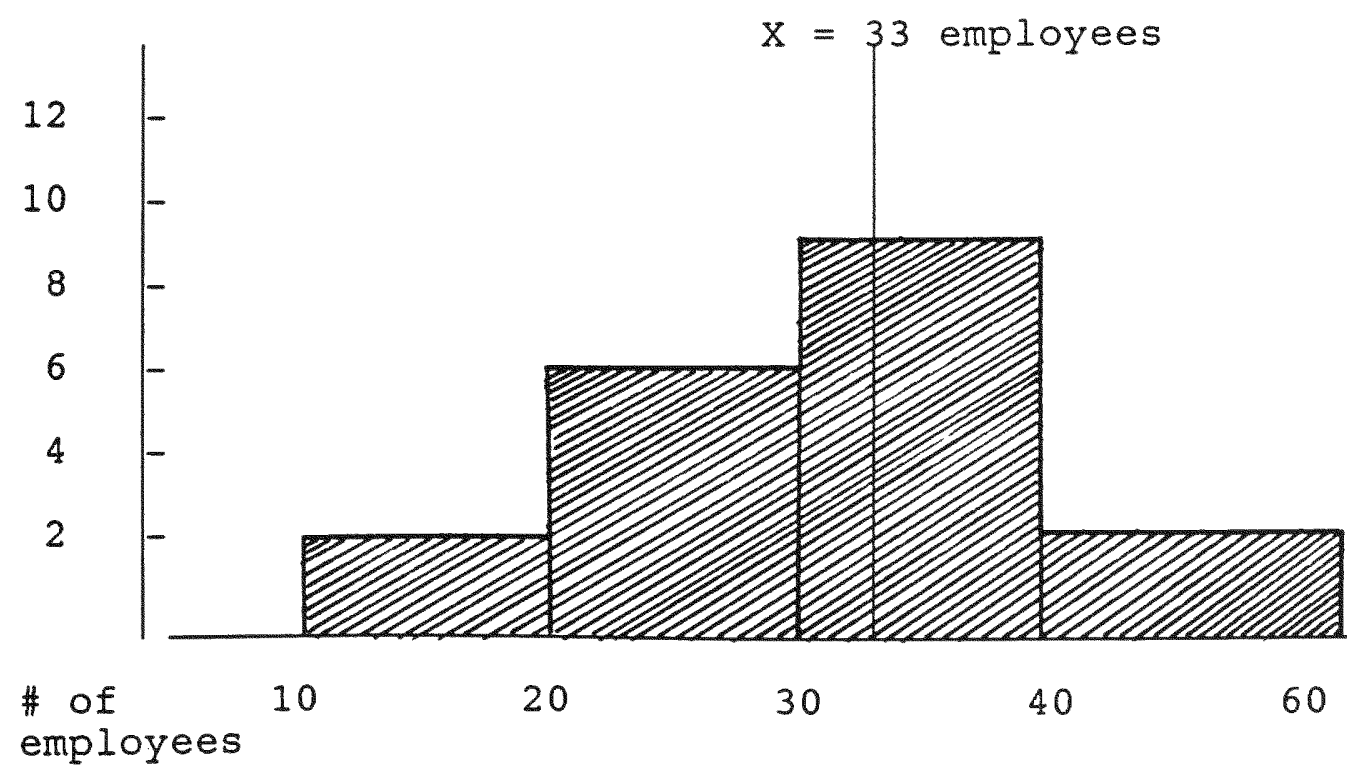


From the above shown information, it is understandable that the "spread" in the number of employees among the selected catering companies is rather large indicated by the great deviation from the means of 33 employees.

The researcher believes that it would be appropriate to note before further analysis proceeds that it was impossible to interpret the following information meaningfully because the sample of those catering companies that use employee hiring programs is very small and any generalization of the results drawn from it would be misleading.

However, it would be helpful to analyze even those responses represented by only an 18 percent of the participating sample, a total of 5 catering companies. These catering companies are being represented by the letters: $A, B, C, D$ and $E$ corresponding to the sequence of results.

- Number of employees in catering departments or catering companies: $20,35,39,43,45$.

- The employee turnover rate in the particular catering companies (years): $1,3,1,4,3$.

- Training has been in existence (years): 1, 2, 3, 3, 4.

- All catering companies had job description, specification and analysis for their employee hiring programs. 
- Employees in catering companies are selected from:

A, B, C, D: Experienced hiring staff

E: Trained by outside professionals

- Trainees are awarded for exceptional performance:

$A, B, E:$ Yes

$C, D:$ No

- The training period for employees of catering companies:

A, B: 1 month

C: 2 months

D, E: All year round

- After the basic training period, additional training is given to employees for all catering companies every year.

- To assess the need for employee hiring, all catering companies use the following approach:

Analysis of problems

Exist interviews

Developing hiring programs

- Objectives of employee hiring programs in catering companies:

A, B, C: All mentioned objectives

$D, E:$ Knowledge and skill objectives

- The following techniques or methods are used in hiring employees in catering companies: 
A, B, C: Job description, job specification and analysis, work sample tests, and interviews. D, E: Job description, specification and analysis, work sample tests, interviews, and conference methods.

- All catering companies had the following sequence in using for their employee hiring:

Determining needs

Job specification

Developing a hiring instrument

Advertising

Evaluation

Verifying

Orientation

B. Assessment of Findings

The research conducted in this study attempted to determine the effectiveness of employee hiring programs in the catering business in the south Florida area. However, only five catering companies or hotels out of nineteen completely responded. Those five were familiar with employee hiring programs. Because most catering companies did not have such a program, the researcher considered it improper to generalize those findings pertained in just 5 companies or the 18 percent of the respondent participants. The following information was gathered to indicate some 
components applicable to those responding catering companies:

- All five catering companies had job descriptions, job specifications for their proper employee hiring programs.

- All five catering companies used the same approach to assess the need for a hiring program.

- Evaluations to measure the effect of proper hiring were attempted but were not well formalized or scientific.

- The managers and supervisors of most catering companies had no specific interviewing skills, resulting in inadequate hiring.

- Most companies should limit themselves to one or two managers who hire employees, as opposed to just managers.

- Based on personality and values, where one manager hired or turned down an applicant, another manager did just the opposite.

- Most catering companies did not have a structured training program. There was no specific designated trainer and this inconsistency of training leaded to new employees being put to work before they were completely prepared causing numerous potential problems.

C. The Hypothesis 
The hypothesis resulting from this study was that the employee hiring programs in the south Florida catering business are generally ineffective.

The researcher discovered that the investigation has been supported and accepted through the information gathered from the survey method.

This conclusion was drawn by the responses of those participants providing no familiarization with employee hiring programs. These participants represented the weighty percentage of 82 percent when compared with the 18 percent of those who do conduct such programs.

D. Concluding Remarks

Most catering companies have long recognized the success of their organizations depend greatly on the quality and competence of their personnel. The research shows all of the variables that contribute to the success and viability of an organization; the most important quality is the working people involved. It is not at all surprising that companies are so eager to attract, hire and retain a productive, satisfied and well motivated staff. Success in recruiting and selecting capable employees who will be an asset to the organization require time, great effort and careful attention in the employment process. These steps and guidelines will improve the catering companies hiring of employees. 


\section{CONCLUSIONS AND RECOMMENDATIONS}

\section{A. Conclusions}

While it is impossible to arrive at a definite conclusion about the ineffectiveness in employee hiring programs in the catering business on the basis of these survey results, a number of observations can be made about the factors that will influence the catering business over the next decade.

Many industry observers have projected continued growth in the catering business. If these forecasts prove accurate, the owners or managers of the catering companies will presumably meet the need of the increase in demand for employees. Most catering companies have long recognized that the success of their organizations depends on the quality of their employees.

In conclusion there were many external factors which contribute to the catering companies' employee hiring problems.

First and foremost, the major reason for these problems was caused by the weak management itself.

In their attempt to use a hands on management system, to get actively involved with their employees and their work, the researcher had hoped that morale would increase. This, however, has not been the case.

Another problem was communication: the lack of 
communication between the management and the employees. Most of the managers of catering companies were not from Miami. This created a bit of culture shock on the parts of both manager and employee. The managers could quickly find out that Miami employees were quite different than the upper east coast employees which they were accustomed to. Miami workers were on a whole, at a different level of "need" than the catering companies' employees their management was familiar with.

B. Recommendations

1. The management must develop seminars for the management team or the specific manager on conducting an interview. Management must learn what to look for when screening and hiring an individual because if a "wrong person" is hired, no matter how well the employee is trained, or how comfortable the work environment is, the individual will not work out positively.

2. Employees should be given a complete description of the job they are being interviewed for, the hours required, the goals of the catering company, and the expectations of their work performance. Therefore if a potential employee has different job expectations it should be discussed before any additional time and money is wasted on the 
individual.

3. The exit interviews should be conducted. By conducting such an interview management should be able to get some insight on why the employee is leaving. Hopefully this will decrease the turnover rate.

4. As the researcher stated earlier, a structured training program must be developed in a catering business. If necessary, the management team should call in a consulting group or buy tapes and manuals, but the money must be spent to properly train the prospective employees. The benefits of the program surely in the long run will outweigh the initial outlay of costs.

5. The catering company should conduct a multicultural seminar for the management team. Since South Florida is such a diverse ethnic environment, the management staff should be made aware of the different goals and needs of the people working for them. Miami is continually changing, the city is multicultural, and the industry needs to meet the needs of their changing workforce.

6. An internal promotional system should be developed. In such an environment dishwashers 
could possibly see a future with the catering company as a manager or head chef. If top positions are only filled from the outside, and a line cook sees no room for advancement, he will become very discouraged and unmotivated.

7. A bonus system should be established for all levels of the employees. Whether the bonus be monetary or some other type of honor and reward, such attention will be a superb motivator, not only for the honored staff, but for the new employees as a whole.

8. Benefit packages and "employee's rights" should be made public and available. New employees sometimes feel uncomfortable about asking a manager about sick days, vacation days, or salary increases. Such policies should be handed out or posted so that all employees are aware of what is due them.

9. The hiring staff in the catering company must establish a new interviewing policy. This policy should stress the need to focus on job related characteristics of applicants, provide practice in questioning and listening skills. In addition, the emphasis on gathering job related information should have preparatory steps before the 
interview. The personnel professionals or managers in the catering company should review the job description, job specification, application and reference checks. Additionally they should determine the areas of inquire, provide for appropriate surroundings and allocate enough time.

10. Finally, the management team along with the corporate heads must make their catering company the most desirable place to work. By doing this even if employees are making a dollar less than the competition, they will want to join their company because they feel motivated, are happy and look forward to going to work. 
SELECTED BIBLIOGRAPHY

BOOKS

Bowes, Lee. No One Need Apply, Boston, MA: Harvard Business School Press, 1987.

Brownfield, Robert L. and Jones, Warren R. Recruitment and orientation, Atlanta, GA: U.S. Government Printing Office, 1985.

Glew, George. Advances in Catering Technology, London, England: Applied Science Publishers, Ltd., 1980 Gove, Philip Bobcock. Webster's New International Dictionary, 3rd edition, The Merriam-Webster Co., Inc., 1986.

Hawk, Roger H. The Recruiting Function, New York: American Management Association, Inc., 1967.

Hayter, Roy. A Career in Catering, Pergamon Press Co., Inc., 1980 .

Leedy, Paul D. Practical Research, 3rd edition, New York: Macmillan Publishing Co., Inc., 1985.

Moore, Russel F. AMA Management Handbook, New York:

American Management Association, Inc., 1970.

Morea, Peter C. Guidance, Selection and Training, Boston, MA: Routledge \& Kegan Paul Ltd., 1972.

Oh, Jung H. Hotel Catering, Seoul: Gimunsa Co., Inc., 1985. Stretch, J.A. and southgate, H.A. The science of catering, 
London: Edward Arnold Publishers, Ltd., 1986. JOURNALS

Aikin, Olga. "Value of Work is the Key," Industrial Caterer, November/December 1985.

Algar, Bruce S. "How to Hire in a Hurry," Personnel Journal,

September 1986 .

Biscott, Lynn. "Effective Recruitment and Selection,"

Canadian Manager, Spring 1986.

Campbell, John and Wernimont, Paul. "Sign, Samples, and

Criteria," Journal of Applied Psychology, 1968.

Farrell, Barry M. "The Art and Science of Employment

Interviews," Personnel Journal, May 1986.

Gatewood, Robert D. and Feild, Hubert S. "A Personnel

Selection Program for Small Business," Journal of Small

Business Management, October 1987.

Harris, Max. "Learning from the Contract Caterers,"

Industrial Caterer, December 1984/January 1985.

Herring, John J. "Establishing an Integrated Employee

Recruiting System," Personnel, 1986.

Magnus, Margaret. "Recruiting Advantages," personnel

Journal, August 1986.

Martin, Bob. "Recruitment Adventures," Personnel Journal,

August 1987.

McEvoy, Glenn M. "Small Business Personnel Practices,"

Journal of Small Business Management, October 1984. 
Slavenski, Lynn. "Matching People to the Job," Training \& Development Journal, August 1986.

Solomon, Robert J. "Using the Interview in Small Business," Journal of Small Business Management, October 1984.

Tradewell, Jay. "Off-Premise Catering: How to Advertise," Restaurant Hospitality, May 1987.

Tradewell, Jay. "The Successful Route to Catering," Restaurant Hospitality, January 1987. 


\section{APPENDICES}

Questionnaire on Employee Hiring Program

1. What field are you in?

Food and beverage

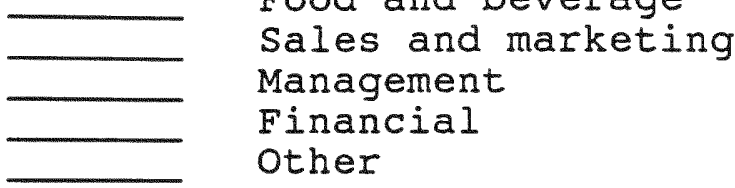

2. Age (please check only one)

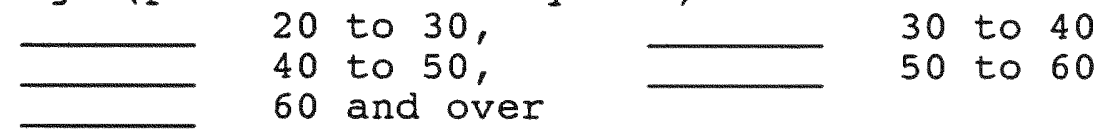

3. Education level

High school graduate

- Bachelor degree

Attended graduate school

Master degree

Other

4. a) What category best describes your operation at this location? (please check only one).

Resort hotel

Commercial hotel

Motel

Restaurant

Other

b) What category describes your operation at this location?

On-premise catering

off-premise catering

Other

(please specify)

c) Type of property

Chain

Franchised

Independent

other

(please specify) 
5. How many people are employed in your department (catering) or company at different types of employees? Manager Supervisor Employee

6. What percentage of total company income was represented by catering sales during last year?

7. What approach does your company use to hire appropriate employee for a proper selection decision? (Please check all appropriate categories). Interview

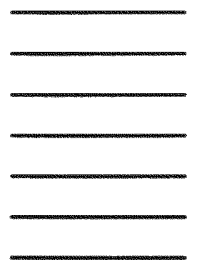
Tests Application form Job specification Experience form Work sample tests other

8. Which of the following interviewing techniques are used for employment?

The "tough guy" interview

The intellectual discourse interview

The "client-centered" counseling interview Other

9. In order to solve the ineffectiveness of hiring the appropriate employee of catering business, which of the following programs would you like to be recommended? (Please check all appropriate categories).

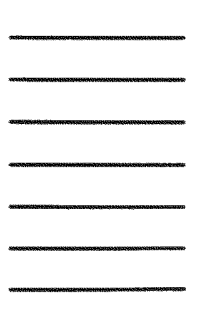
Food preparation Accounting Human Behavior Work sample tests Language education Practical Training Other

10. What methods do you use to evaluate hiring program? Written/verbal exam Direct observation Study of records and reports Analysis of problems 
11. What is your employees turnover rate in your company? (Please circle on years).

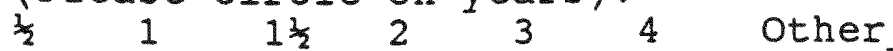

12. How are the employee hiring staffs selected?

Inhouse (catering department)

- Experienced staff member

Hired by outside professional

13. How long is the training period for new employees after they are hired?

14. What are the objectives of the employee hiring programs in your company?

Attitude objectives

Knowledge objectives
Skill objectives
Job-behavior objectives
Other objectives

15. When you evaluate new applicant (employee) which characteristics are important? (Please check all appropriate categories).

\begin{tabular}{l}
- Voice and speech \\
Appearance \\
Alertness \\
\hline Ability to present idea \\
Judgment \\
Emotional stability \\
Self-confidence \\
Other
\end{tabular}

16. What is important for new employees in your company? please answer each of the following responses. ( 1 is the least important, 5 is the most important).

Working condition

Motivation

Salary

Amount of working hours

Benefits

Need for new challenge

Company image

Physical demands of job

Others

$\begin{array}{lllll}5 & 4 & 3 & 2 & 1 \\ 5 & 4 & 3 & 2 & 1 \\ 5 & 4 & 3 & 2 & 1 \\ 5 & 4 & 3 & 2 & 1 \\ 5 & 4 & 3 & 2 & 1 \\ 5 & 4 & 3 & 2 & 1 \\ 5 & 4 & 3 & 2 & 1 \\ 5 & 4 & 3 & 2 & 1 \\ 5 & 4 & 3 & 2 & 1\end{array}$


17. Which of the following sequence are used in employee hiring of your company? (Please check all appropriate categories). Determining needs Developing job specification Preparing to fill the position Developing a hiring instrument Advertising Evaluation Verifying Orientation Other

18. Do you consider employee hiring programs of your company successful? If yes, why?

If no, why?

19. Do you think the current employee hiring programs of your company are good enough proper employee to meet the needs of the catering business? Yes

No If no, why?

20. Do you wish to make any other comments that would help the development of good hiring programs in the catering business?

(Any guidance will be most helpful for me). 
THE QUALIFICATIONS OF THE RESEARCHER

The researcher was born in Seoul, Korea, on August 13, 1959. He completed his junior and senior high school education in the spring of 1979 in Seoul, Korea.

After graduating from high school he entered Inha University, which is located in Incheon, a city near seoul, in March 1979, majoring in foreign languages (English) education. In August 1983, he earned a Bachelor of Arts degree in English Language Education and he received an award for academic excellence. After he graduated from the University, he continued his studies for the graduate course in the same university and worked as a teaching assistant in his department until July 1985.

In August 1985, he proceeded to the United States for further studies. He entered Florida International University as a Master degree-seeking student in the Hospitality Management Program in September 1985.

During the summer of 1987 , he returned to his country and got married with his lovely wife.

At the present time, he is expecting to receive his Master of Science Degree in Hospitality Management. 